\title{
Assessment of employees attitudes toward ongoing organizational transformations
}

Article

Accepted Version

Heim, I. ORCID: https://orcid.org/0000-0003-3023-4839 and Sardar-Drenda, N. (2021) Assessment of employees attitudes toward ongoing organizational transformations. Journal of Organizational Change Management, 34 (2). pp. 327-349. ISSN 0953-4814 doi: https://doi.org/10.1108/JOCM-04-20190119 Available at https://centaur.reading.ac.uk/94422/

It is advisable to refer to the publisher's version if you intend to cite from the work. See Guidance on citing.

To link to this article DOI: http://dx.doi.org/10.1108/JOCM-04-2019-0119

Publisher: Emerald

All outputs in CentAUR are protected by Intellectual Property Rights law, including copyright law. Copyright and IPR is retained by the creators or other copyright holders. Terms and conditions for use of this material are defined in the End User Agreement.

www.reading.ac.uk/centaur 
Central Archive at the University of Reading

Reading's research outputs online 


\section{Journal of Organizational Change Manag}

\section{Assessment of employees attitudes toward ongoing organizational transformations}

\begin{tabular}{|r|l|}
\hline Journal: & Journal of Organizational Change Management \\
\hline Manuscript ID & JOCM-04-2019-0119.R3 \\
\hline Manuscript Type: & Research Paper \\
\hline Keywords: & $\begin{array}{l}\text { Organizational change, Individual willingness and ability to change, } \\
\text { Change management, Digital service industry }\end{array}$ \\
\hline \multicolumn{2}{|l}{} \\
\hline
\end{tabular}

\section{SCHOLARONE \\ Manuscripts}


ASSESSMENT OF EMPLOYEES ATTITUDES TOWARD ONGOING ORGANIZATIONAL TRANSFORMATIONS

\section{INTRODUCTION}

Digital service companies are currently facing several challenges. These challenges are diverse, ranging from the strategic and operational levels to issues of people management. The operational challenges include the need for ongoing organizational transformations as a result of technological acquisitions, and the adoption of new technologies and business models (Berman, 2012). Christensen $(1997 ; 2013)$ suggested that a change in technology can give new entrants a significant advantage, therefore existing companies need to constantly update. Consequently, low levels of satisfaction are often reported amongst the employees (Bersin et al., 2017). Moreover, the digital service industry is racing towards automation and digitalization - focusing on the delivery of big data and security services - and employees do not possess the right skills to support the changing business portfolio. When such global organizations are diversified and include different businesses through acquisitions, there are coordination problems (Goold \& Campbell, 2002). In these settings, change management is a critical organizational skill set, dealing with the entrenched inability of organizations to adopt behaviors that would allow them to embrace new technologies (Flanding et al., 2018). Lack of knowledge leads to high costs, lower profit margins, and slow proliferation of automation and industrialization. Transition and transformation projects are challenged financially; the processes are complex. These factors result in dissatisfaction amongst the employees and lead to many employees sitting through the change. However, an attempt to change can have a positive or negative impact on attitude and productivity (Weber \& Weber, 2001; Piderit, 2000). In the such a complex settings, most change efforts fail (Rafferty et al., 2013) and this alone is the main reason for taking a new and careful theoretical approach to those transformations to 
which extant theories are not easily applied (Robinson, 2019). In this study we consider a topdown approach to change management, since this change dynamic is the most typical for digitalization-induced organizational transformations, which are often are results of the new strategy implementation at the organizational level. However, the change supportive behavior is important for successful implementation of planned change (Miller et al., 1994; Rafferty et al., 2013), and therefore we study the internal enablers affecting employees' attitudes toward change, i.e. what enables employees to facilitate organizational change.

While the failure to successfully implement planned change may be attributed to many factors, few issues are so critical as employee's attitude to change (Miller et al., 1994). Kotter $(1995 ; 2012)$ suggested that most transformation efforts fail because people do not understand the need for change: employees' responses may be positive and supportive, or they may be negative - or even directly oppositional (Vakola \& Nikolaou, 2005). Change-supportive behaviors can be defined as "actions employees engage in to actively participate in, facilitate, and contribute to a planned change initiated by the organization" (Kim et al., 2011). The purpose of this study was to find the predictors of employee's attitudes towards change measured by a willingness and ability to change and specify what the key underlying factors impacting employees' change-supportive behavior are, in order to plan an ongoing change.

Although many organizations are currently faced with the challenge of adapting to a rapidly changing and often unpredictable environment, the underlying concepts of the change process remain relatively simplistic (Buono \& Kerber, 2010). Therefore, organizations would like to understand what the role of employees' willingness and ability to adapt strategically when a strategy has been successfully implemented. Since the strategic change is often in the "non-disclosure" phase, it is nearly impossible to measure the readiness of the employees to

\footnotetext{
${ }^{1}$ i.e. the context of the upcoming change was not known to the employees since it either cannot be announced before the Works Council approve it (see the Research Design section below), or is in the preliminary stage when discussed at the top-management level etc.
} 
successfully adopt the change using one of the existing frameworks (Wanberg \& Banas, 2000; Bouckenooghe, Devos \& Van Den Broeck, 2008; Rafferty et al., 2013). Therefore, the only way to measure the general willingness and ability to change as employee attitude indicators is by using a simplified approach adapted from existing frameworks of readiness.

This research addresses the need for a more employee-oriented approach in the study of change (Vakola, 2014) with a focus on internal enablers of change readiness. It uses an abductive approach and seeks to refine existing theories, rather than invent new ones (Dubois \& Gadde, 2002). It includes the process of reasoning from data collection to understanding of observed patterns (Robinson, 2019).

\section{LITERATURE: THE CONCEPT OF INDIVIDUAL CHANGE READINESS}

Literature on the topic of change defines it as the deliberate introduction of novel ways of thinking, acting, and operating within an organization as a way of surviving or accomplishing certain organizational goals (Schalk et al., 1998). In these terms, it is very similar to innovation, in which effectiveness is found to be a function of (a) the strength of an organization's climate for the implementation of that innovation and (b) the fit of that innovation to targeted users' values (Klein \& Sorra, 1996). Change can be also viewed as a process of altering the present shape/estate to become a better one (Bäesu \& Bejinaru, 2014). Change can be analyzed from different perspectives and can therefore include individual or organizational foci. Cameron \& Green (2004) place individual change at the heart of everything that is achieved in organizations. An increasing number of researchers believe that many change efforts fail because change leaders often underestimate the role individuals play in the change process (Choi, 2011).

Previous studies examining the conditions in which employees support organizational change have focused on various concepts explaining employees' responses towards 
organizational change, defined as certain regularities of an individual's feelings, thoughts, and predispositions to act toward some aspect of the environment (Secord \& Beckman, 1969; Rafferty \& Minbashian, 2019). This includes resistance (Oreg, 2006), readiness for change (Armenakis et al., 2007), openness to change (Wanberg \& Banas, 2000), commitment to change (Herscovitch \& Meyer, 2002), and cynicism (Wanous et al., 2004). These constructs have been defined in Table 1 .

\section{Insert Table 1 about here}

The success - or even survival - of a company strongly depends on whether their employees embrace readiness to change and adaptive abilities to achieve a sustainable competitive advantage (Pan \& Sun, 2018). Research has recently begun to suggest insights about organizational change from individuals' perspectives (e.g., Bartunek et al., 2006; Oreg et al., 2011; Oreg et al., 2016). Weiner (2009) argues that in ordinary language the term "readiness" connotes a state of being both psychologically and behaviorally prepared to take action (i.e. willing and able) which strongly supports the selection of the attitudinal construct (i.e. attitudes to change). Change readiness is, therefore, one of the most often used attitudes toward change (Bouckenooghe, 2010), and, therefore, will be addressed in this research.

Like change itself, readiness for change is a multi-level construct and can be present and studied at the individual, group (unit, department), and organizational levels (Weiner, 2009). Despite the importance of the change readiness concept for successful implementation of the change in organizations, individual readiness as a stand-alone concept in an organizational context does not appear in the literature (Vakola, 2013), thus creating interest for further research and theorization. Recent studies suggested several models of individual readiness for change, e.g. with a focus on job satisfaction (Shah et al., 2017). However, this research uses a 
survey of the academic staff of public sector higher educational institutions in Pakistan, and therefore, cannot always be directly applied to the private sector where performance is profit related. Additionally, as Nink and Welte (2011) stressed, to make employees feel completely involved in the organizational change, satisfaction with the workplace alone is not enough. The first steps considering the central, active roles change recipients play in organizational change events were recently conducted by Oreg et al. (2016).

Although employee attitudes toward change are a key factor that determines the success of an organization's change efforts, much of the research focusing on issues relevant to organizational change has focused on organizational-level concerns rather than individuallevel concerns (Elias, 2009). Two main concepts have been used to explain employee attitudes toward change: the concept of resistance for change and the concept of change readiness (Bouckenooghe, 2010). Other concepts that emerged are: openness to change, change cynicism, and others (see Table 1). Employee responses toward change can be classified into four groups: cognitive, affective, intentional, and behavioral (Repovš, Drnovšek \& Kaše, 2019). In the first instance, research defined resistance to change as behavior intended to avoid change (e.g., Herscovitch, 2003). Later, other dimensions such as intentional, cognitive, and affective dimensions were included (del Val \& Fuentes, 2003). The contemporary view is that resistance to change is a multidimensional attitude (Oreg, 2006). Readiness for change is a more recently developed concept, defined as the cognitive precursor to the behaviors of either resistance to, or support for, a change effort (Armenakis, Harris \& Mossholder, 1993). Researchers agree that readiness for change has similar dimensions as resistance to change, but the former concept entails not the behavioral dimension, but the cognitive, affective, and less intentional ones (Armenakis Harris, \& Mossholder, 1993; Cunningham et al., 2002; Holt et al., 2007; Weiner, 2009; Holt \& Vardaman, 2013). Although change resistance may exist alongside change readiness, the later concept provides us with the foundation for sound theorizing, and 
for managing challenges related to individual readiness for change in organizations, and therefore will be used as the theoretical basis in this research.

Individual readiness for change can be influenced by broader factors (Cunningham et al., 2002). The literature distinguishes between three categories of antecedents for individual readiness: external organizational pressures, internal context enablers, and individual characteristics (Rafferty et al., 2013; Schein, 2010). This study is focused both on internal context enablers and some individual characteristics of employees, and on change management issues related to these factors (Armenakis \& Bedeian, 1999). Weiner (2009) noted that change readiness means being willing and able to change. The construct of willingness to change is adapted from the constructs of emotional readiness to change. As proposed by Bouckenooghe et al. (2008), individuals believe that they are ready for change and perceive change as a positive challenge. The construct of ability to change is borrowed from the efficacy component of change readiness as proposed by Armenakis and Harris (2002). This component is related to the questions "can I/we successfully implement the change?" If employees do not have the confidence or emotional intelligence to adopt new ways of operating, and if emotional capability at the organizational level is missing, the change outcome can be adversely affected (Huy, 1999). A similar construct - "change related self-efficacy" - was proposed by Wanberg and Banas (2000) as a predictor for openness to change. They argued that individuals will not perform well in a changing context when they are not aware of their abilities. There are several models of change, readiness, and openness, however, no models were found which analyzed the willingness and ability to change together as the employees' attitudes towards change.

Individuals, teams, and organizations all play a part in the process of change, and leaders have a particularly onerous responsibility: that is, making "all this" happen (Cameron \& Green, 2009). Bäesu and Bejinaru (2014) suggested that it is a leader's job to create change readiness, and that an employee's readiness to accept change is critical for the process of success. Higgs 
and Rowland (2000, 2005) linked leadership behaviors to activities involved in implementing change. This includes shaping behavior (actions related directly to the change), framing (establishing starting points for a change), and creating (connections between individual and organizational capabilities, and communication and marketing of the change). For example, Berneth (2004) suggested that communication of the change is the primary mechanism for creating readiness for change among organizational members. Additionally, leaders can adopt an "energizing" leadership strategy (Bruch \& Vogel, 2011) to transform the spirit in the organization from toxic to winning.

A review of the literature reveals a small number of publications on topic dealing with resistance to change and change readiness (Repovš, Drnovšek \& Kaše, 2019). This paper aims to contribute to the research and practice on individual change readiness, building on the concept of change readiness and its relationship with employees' willingness and ability to change, as well as internal context factors that can be affected by leadership strategies. We explore internal context change readiness enablers, as well as leadership change strategies in the business context of the global digital service company. Figure 1 below summarizes the concepts that constitute and affect employees' readiness and willingness to change.

\section{Insert Figure 1 about here}

\section{THE RESEARCH DESIGN}

Since few researchers have attempted to develop the models of organizational change (Decker et al., 2012), and with the willingness and ability to change at an individual level remaining under-researched, the selected strategies of this study were abductive, i.e. they 
applied a process of reasoning to data in order to understand it, and observed patterns in order to offer the framework of underlying variables. One of the main reasons of why organizational initiatives fail is the lack of a thorough diagnostic investigation in an organization's readiness and risk for a planned change (Pellettiere, 2006). In this sense our research complements practice literature, including the Q12 survey conducted by Gallup Corporation (Hoogerhuis \& Anderson, 2019), which suggests that through qualitative and quantitative data on people's change readiness, leaders can discover ways to unify employees behind a change initiative. We begin with simple logic to guide the exploration of the data and go on to develop plausible explanations for the results. In doing so, we aim to extend and enrich the theory. We used the abductive approach as the extant theories were fragmented and not easily applied, given the complexity of the phenomenon, or the context and goals of this research (Robinson, 2019). The aim of abductive research is to combine data-gathering with analysis in incomplete observations, comparing the evolving framework with existing literature-based theory and including both inductive and deductive elements (Frow et al., 2015). An abductive inquiry is particularly appropriate when pursuing theory development, i.e. refining existing theories rather than inventing entirely new ones (van Echtel et al., 2008). From the theoretical perspective, we used a concept of change readiness as an attitude comprised of cognition and affect (Holt et al., 2007a). We constructed the predictors of a change readiness based on the review of prior literature (see Appendix for the list of predictors and relevant questions).

We collected data to study the determinants of the willingness and ability to change using a mixed-methods approach, with exploratory interviews followed by a web-based survey with both closed and open (qualitative/inductive component) questions (the quantitative/deductive and qualitative/inductive components, respectively) (Hanson et al., 2005; Jansen, 2010). This approach is particularly important because it allows us to understand the internal enablers which are most typical for the selected sample (the questionnaires offer breadth of research), 
and at the same time to understand why (interviews and open-ended questions offer depths of understanding). The research design of the questionnaire is based on the main measures of willingness and ability to change collected from the academic literature. This allows us to apply deductive reasoning. The formulation of questions was guided by the mixture of theoretical approaches proposed by Wanberg and Banas (2000), Bouckenooghe et al. (2008), and Rafferty et al. (2013). The variables in this study compiled from academic sources are summarized in Table 2.

\section{Insert Table 2 about here}

The research was conducted in a German subsidiary of a global digital service company (the Organization) with more than one hundred thousand employees and a revenue of more than $€ 10$ billion annually. According to Forbes (2018), the organization is on the list of 100 top digital companies in the world. From July to August 2018, all employees from offices located in 4 cities (2310 people in total) were invited to participate in the survey. 549 were on holiday and 306 employees replied to the online survey, which came to a total response rate of $17.39 \%$. The respondents included both employees and managers; however, we do not know the distribution of the answers between these two groups, since it was not approved by the Works Council $^{2}$. Focusing on one country allowed exclusion of the influence of different laws and national culture effects on the behavior of respondents. In total, 249 male and 47 female participants responded, including $3.92 \%$ aged 30 or younger, $42.48 \%$ between 31 and 50 years old, and $53.6 \%$ aged 50 years or older. The distribution of age and gender of the respondents is normal as it reflects the demographic distribution in the company. Most of the participants

\footnotetext{
${ }^{2}$ In German companies, the Works Councils (WCs) play an extremely crucial role to ensure the welfare of the employees. WCs at regional levels and different legal entities represent employees in the management of the organization.
} 
had more than 20 years of work experience in the company (50.98\%), more than a third of the employees had 11-20 years of experience (31.05\%), and the rest had less than 10 years of experience $(17.97 \%)$.

\section{Quantitative component: surveys}

The survey comprised 52 multiple-choice questions and free-text comments. Multiple choice answers and a scale of 1-4 were used where: 1 - strongly disagree; 2 - slightly disagree; 3 slightly agree and 4 - strongly agree. The SPSS statistical tool was used to analyze the primary data. To find an association between variables, Spearman's rank correlations were used. Values of from 0.3 to 0.7 were considered valid moderate correlation scores, and values above 0.7 as strong correlation scores. Analysis of variance techniques includes the Mann-Whitney test for two independent samples, such as gender, and the Kruskal-Wallis test for more than two independent samples, such as age, level of job seniority, the company background, and job function. The free-text comments from the respondents are coded into themes and represented in percentage to the total (See Table 3 below).

\section{Qualitative component: interviews}

For the interviews, fifteen employees who were aware of an upcoming change were selected and invited, of which nine participated in the interviews. The interviews were based on 17 questions covering aspects of cognitive and emotional readiness. All questions were open-ended, and participants' answers were coded into themes. After the interview, the answers were summarized and sent to the interviews for approval.

The interviews and the open questions in the survey were coded in Excel and the output is shown as a percentage of the total. The responses to the interviews were integrated into analysis wherever it is appropriate. 


\section{THE RESULTS AND DISCUSSION}

The overall willingness to change was measured based on the answers to the question: "I feel I am ready for another organizational change" (emotional readiness). The open-ended questions revealed that employees were ready for an internal job change only when it was meaningful (see Table 3 below). Overall, it can be concluded that employees are willing to change only if the upcoming change makes sense to them (Lawrence, 1969). This confirms the importance of the valence component of cognitive change readiness proposed by Armenakis et al. (1993).

\section{Insert Table 3 about here}

To plan the best possible change intervention, it is important to examine whether there are differences in the degree of willingness to change amongst groups of employees. There were several categories of employees identified for this investigation such as age, gender, job function, company background, and years of experience (job seniority). It was found that age and level of seniority in the company had an impact on willingness to change, as older and more experienced people were more pessimistic towards change. However, no evidence was found that gender, company backgrounds or job function determine willingness to change.

We found three potential reasons behind this impact. Firstly, people who have been working in the company for longer have lived through several organizational changes and have criticized the change management capabilities in the Organization. Secondly, the desire for job comfort and job stability is greater in senior employees. Thirdly, the fear of being unemployed is also greater in senior employees above the age of 55 and older. Therefore, agreeing to change jobs without knowing the impact of this change (personally) is an unlikely behavior in this age 
category. While previous research has demonstrated that age alone accounts for little variance in work performance in relatively stable work contexts, it is plausible that adaption to changes in work settings might become more difficult with age (Niessen et al., 2010). Contrary to this common stereotype, Kunze et al. (2011), has found that the age of employees correlates negatively with resistance to change. Our findings suggest that age can have mixed non-linear effects on the individual's attitudes to change.

The overall ability to change was measured based on the answers to the question: " $M y$ prior experiences make me confident, that I will be able to perform successfully after an organizational change is made”. It can be assumed that an employee's belief in his or her capabilities to support a change is the best measure to assess the general ability to change in the Organization. The open-ended questions discovered that employees wish processes and pools to be a part of restructuring and change as well.

Similar to the willingness to change questions, we surveyed several groups of employees for their ability to change. Evidence has been found that only the company background has an impact on the responding tendencies for the ability to change in the Organization. The impact of company background can be explained by the effect of previous changes. Employees with different company backgrounds can have different attitudes to change. This finding is consistent with what is already known, i.e. that organizational culture (or the background organization in our study) plays an important role in the change process (Schneider \& Brief, 1996; Silvester \& Anderson, 1999; Rashid et al., 2004; Jones et al., 2005).

\section{Impact of internal enablers}

To better understand the individual conditions for change-supportive behavior, it is important to analyze the impact of internal context enablers on the willingness and ability to change. 
Job satisfaction. The satisfaction of the employees in their job was measured by the question: "Are you satisfied in your current job?". No significant association between job satisfaction and willingness and ability to change was found. Therefore, it can be concluded that despite the average scores for job satisfaction $(58.46 \%$ of the respondents chose options for slightly satisfied and strongly satisfied), it does not seem to impact the willingness and ability to change in the Organization. Although previous research suggested that satisfaction with communication has significant positive effects on workers' perception of readiness for change in some organizations (Claiborne et al., 2013), our research found that overall job satisfaction is not a predictor of the readiness to change. This is in line with Nink and Welte (2011), who suggested that satisfaction with the workplace alone is not enough for greater readiness to change.

Individual perception of organizational culture. The individual perception of organizational culture is measured in this research by three questions. The first question was "I am aware of the values of the organization and can identify myself with them". It aims to measure the awareness and identification of employees to the values of the Organization. The values are set company-wide and are listed on the website.

A moderate positive correlation was found between the question "I am aware of the values of the organization and can identify myself with them" and the ability to change. As a result of this, it can be concluded that employees who are aware of the values and vision of the organization have a greater belief in their capabilities to cope with change. A test of variance has been conducted for all the identified groups of employees for the question "I am aware of the values of the organization and can identify myself with them", as this question shows a moderate positive correlation with the ability to change. It was found that only company background has an impact on the scoring tendency for values of the Organization and identification with them. The organizational culture is understood in this research as a set of 
shared meanings that make it possible for members of a group to interpret and act upon their environment (Schein, 1984). Based on secondary sources of information, it can be concluded that as a result of the previous change (M\&A of two European companies) and of rapid acquisition-based growth in recent years, the Organization has two distinct groups of employees. It can be concluded that past culture (different in these two companies) may affect the perception of organizational values and may therefore affect the ability and willingness to change if employees do not identify themselves with the "new values". This is consistent with findings related to the company background (see discussion above).

Understanding the need and urgency for change. The need and the urgency for change are measured in this research by three statements: "I understand the current organizational challenge in the organization", "My direct and executive management communicates regularly on the current challenges in the organization", and "I understand that there is a need for change in the organization as soon as possible".

The statement "I understand the current organizational challenge" also has a moderate positive association with willingness to change measured by the response to "I am ready for another organizational change" and ability to change measured by the response on "My prior experiences make me confident, that I will be able to perform successfully after an organizational change is made" which means employees who understand the current organizational challenges in the Organization are also more willing and able to change.

A moderate positive association found between "I understand that there is a need for change in the organization as soon as possible" and "I am ready for another organizational change" shows that an employee who understands there is an immediate requirement of change also feels ready for an organizational change. Therefore, a test of variance for all groups of employees for "I understand the current organizational challenges in the organization" and "I understand that there is a need for change in the organization as soon 
as possible" was conducted. It was found that job function has an impact on understanding the challenges in the organization ("I understand the current organizational challenges in the organization"). It was also found that gender has an impact on employees' reactions to "I understand that there is a need for change in the organization as soon as possible". The responses to "I understand the current organizational challenges in the organization" differ among different departments. This can be explained by considering that some groups of employees have a better overview of processes and finances, and therefore a greater understanding of the need for change. This factor was proposed by Arnemakis et al. (2007) as a component of change readiness which reflects a belief that change is needed. In this research we extended this factor adding the urgency for change as a measure of awareness of the challenge.

Individual perception of organizational capabilities to change. This factor is measured in this research by four responses "I believe that the organization has been able to cope effectively with new situations" (61.1\% of respondents disagreed with the statement), "I believe that past changes in the organization resulted in improvements" $(72.55 \%$ of respondents disagreed with this statement), "I believe that the organization has proven itself capable of implementing organizational changes" $(62.09 \%$ of respondents disagreed with this statement), "The organization generally provides appropriate support when needed to cope with organizational changes" (67.32\% of respondents disagreed with the statement). Table 4 (below) shows that $10.46 \%$ of respondents chose to add free-text comments on this section. The main themes addressed in these comments were dissatisfaction about working in the Organization, which included processes, tools, management and near and offshoring strategies, dissatisfaction about past change, and lack of trust in change implementation capabilities in the Organization. The participants highlighted the requirement of including processes and tools in restructuring measures. 


\section{Insert Table 4 about here}

A moderate positive correlation was found between the two questions "I believe that past changes in the organization resulted in improvements" and "My prior experiences make me confident, that I will be able to perform successfully after an organizational change is made", and the ability to change (see Table 5 below). This means the Organization's capability to change has an impact on the ability to change of an individual in the Organization: in other words, when employees believe that past change has brought improvements, they tend to believe that they can cope with a future change and perform successfully. The responses on the question "I believe that past changes in the organization resulted in improvements" indicated that all groups of employees have the same tendency to respond to these questions. This corresponds with Choi (2011) who suggested that an organization's ability to accommodate changing situations has a great impact on individual change readiness.

\section{Insert Table 5 about here}

Communication in the organization. The quality of communication in the Organization was measured with three questions. The first question was "The communication I receive from the organization centrally is timely and useful", which $53.26 \%$ of the respondents agreed with. The second question was "Information on upcoming changes first come to us mostly as rumors", which $83.07 \%$ of the respondents disagreed with, and the third question was "My line manager and executive management communicate on a regular basis on upcoming changes", which $60.68 \%$ of the respondents agreed with. The topmost categories of comments suggested that the timing and content on change communication do not meet 
expectations, followed by allegations that news on upcoming change mostly comes as rumors.

For all the questions in communication in the Organization, the correlation is weakly positive and so no significant relationship has been found with willingness and ability to change. This is different from what was suggested in previous research, i.e. that the failure to provide sufficient information or providing poor-quality information can result in several problems, including cynicism about change (Choi, 2011). Providing information about the change is probably not enough for complex transformations and more complex interventions are necessary. This can be explained by considering that in this study employees did not know about the planned change, and therefore nothing had been communicated.

Trust in leadership. The questions aimed at testing trust in leadership could not be added to the survey due to the recommendation from the management team. Therefore, this factor was explored in personal interviews only. Two questions were asked to assess the role of trust in leadership. For the first question "In the organization, do you think there is a discrepancy in trust in direct management and trust in executive management?" the answer was positive for all participants. Several reasons were highlighted for this lack of trust. For the second question, "Do you think trust in management plays a crucial role in the success or failure of change efforts?" the answer again was also positive for all the participants. Therefore, this study is compelled to consider this factor as positively influencing willingness and ability to change. This supports the findings of Bouckenooghe et al. (2008), who found trust in top management plays a crucial role in change readiness.

Prior experience with change. Most of the respondents $(69.97 \%)$ referred to the last organizational change they participated in as an acquisition. Upon asking the question if the goal of the organizational change was clear, $43.7 \%$ answered yes, $28 \%$ no and $25 \%$ maybe. For the question "Was the change successful in your opinion?", only 14\% responded "yes", $38.56 \%$ responded "no", and $45 \%$ responded partially "yes" or "no". 
The interviewees were asked to name the most important change management issues. For example, Interviewee 4 said the following in response to the question "what are the main challenges and what can be done better":

"...Set the strategy, involving the employees, lead them to the new organization, focus on the customer, and solve the issues".

Interviewer 5 suggested, "to involve the people in the planning, and in the beginning".

To summarize, no relationship was found between prior experience with change and ability and willingness to change. Based on their prior experience employees would like to be involved and have control over the upcoming change events at the earliest stages. Recommendations provided by the interviewees on the question are summarized in Table 6 below. The most common responses included: increasing transparency, people involvement, and training; demonstrating people's perspective; collecting feedback; and effective communication. However, our finding is different from what is known from prior literature. For example, Rafferty et al. (2013) identified an employee's change history in an organization as a key antecedent of their opinion on organizational change. This difference suggests that although employees recognize the failure of the previous change, they also understand the need and urgency of the new transformation.

\section{Insert Table 6 about here}

Leadership change strategies. The employees were asked what kind of leadership behaviors they wished their leaders to possess during change (according to the leadership change strategies suggested in 2001 by Higgs and Rowland). In the answers to the questions about leadership strategies in the organization, we found that the most typical leadership behavior in settings of organizational change was framing, with shaping and creating less 
typical, suggesting that employees want their leaders to tell the truth about the upcoming change. That is an interesting finding because as per Higgs and Rowland (2011), a leader's shaping behaviors or centric behaviors lead to unsuccessful change (see Table 6 below). Upon asking the question "What type of the motivational strategy do your currently observe in the leadership of your organization?", the employees pointed out that caustic and resigned attitudes are the most predominant symptoms of adverse emotions during the change in the Organization. This finding is consistent with Bruch and Vogel (2011), who suggested both these forms of organizational energy are negative for a healthy business environment.

Figure 2 below summarizes the relationships amongst variables and willingness and ability to change. This Figure demonstrates the relationships between predictors of ability and willingness to changes in their predictors and, therefore, provides insights into the conceptual framework in Figure 1.

\section{Insert Figure 2 about here}

\section{CONCLUSIONS, IMPLICATIONS AND FUTURE RESEARCH}

This research has explored the predictors of individual change readiness as a precursor to organizational change and examined leadership strategies available to help generate readiness. This research discovered that employees are willing to change when the proposed change makes sense to them. Evidence has been found that the following factors have an impact on the willingness and ability to change include: job function (indirectly), age, job seniority, knowledge of values (individual perception of organizational culture), company background, understanding the current challenges and understating the need and urgency for change. Trust in leadership at different levels plays a crucial role in shaping change readiness. 
Our study contributes to the prior research, including the theoretical and practical literature on the effects of work attitudes, emotions, and behaviors on performance. This research also contributes to the practical literature on the conduct of employee interviews on change, including Gallup's Q12 employee engagement framework (Gallup, n/d). We add to the existing literature new dimensions related to prior experience with change and understanding the need and urgency for change - specific factors that are relevant to an individual's ability to change.

Managers can use the findings of this study to learn how to plan and manage organizational change in the fast-paced business environment of digital service industries, which often requires a longer time with a need to extend the organizational restructuring to behavioral and mindset change. This research suggests a practical approach to the assessment of change readiness in the industry where employees represent the main assets of the organization and take an active part in the co-creation of the value propositions with customers (Heim et al., 2018). When planning change, managers should take into consideration that even well-planned change events may not produce the desired outcomes if members are not ready (Armenakis et al., 1993). Some age groups and more experienced employees can demonstrate low levels of change readiness. Change agents in organizations need to pay more attention to vulnerable groups (older and more experienced staff) when planning organizational change. Managers can improve change readiness among these groups through organization events aiming at communication the purpose of a transformation, for example, involving these people in the planning. Knowledge of values, understanding the current challenges, and understating the urgency for change, as well as the development of positive attitudes toward past changes through discussion, can improve the overall readiness for change among personnel.

Change initiatives based on so-called digital transformations - opportunities to create new business models for global digital companies - become more complex and strategic and 
therefore, as recently suggested, there is a need to manage the transition and emotions of employees (Rafferty \& Minbashian, 2018). We propose that the focus should have a long-term perspective, i.e. prior experience with change in the organization and the future change. We also found that people expect more diverse leadership behaviors, including framing, shaping, and creating (Higgs \& Rowland, 2011). Our research highlights interrelations between demographic and internal context variables, which influence willingness and ability to change at the level of the individual in the organization. This study contributes to organizational change literature, suggesting a simple model explaining factors affecting employees' willingness and ability to change.

This research does have its limitations, however: firstly, the context of the upcoming change was not known to the employees. These scores could have been more accurate if the employees had known this. Secondly, since the questions aimed at testing the trust in leadership could not be added to the survey (due to the recommendation from the management team), this research could not explore the reasons behind participants' answers. Such reasons could include the management team not trusting the responses of its employees, refusing to judge itself by its employees, or not confident enough. We also do not know the distribution of the answers between these two groups, since this question was not approved by the Work Council. Also, this research is focused on one organization, and research in other industries and firms in the digital service industry would be beneficial. The effects of ageing on the individual readiness for change would be an interesting avenue for future research. Future research could also explore the individual readiness for change between other categories of employees, including those with and without migration background or experience. Overall, further research needs to explore more about the perception of change strategies in a fast-paced business environment and suggest new theoretical approaches explaining change dynamics. 
Acknowledgments Authors would like to thank the Editorial Team of the JOCM and two anonymous reviewers for their constructive and friendly review and cooperation that allowed us to improve this paper. This paper also benefited from the feedback received from four anonymous reviewers at the Academy of Management Annual Meeting 2020. The authors would like to thank Associate Professor Jane McCormack and Mr. Jack Masters for editing and proof-reading this work. No external research funding received to finance this study.

\section{REFERENCES}

Alas, R. (2008), "Employees willingness to participate in implementation of organizational change", Management of Organizations: Systematic Research, Vol. 46, pp. 7-15.

Armenakis, A. A. and Bedeian, A. G. (1999). "Organizational change: A review of theory and research in the 1990s", Journal of Management, Vol. 25 No. 3, pp. 293-315.

Armenakis, A. A., Bernerth, J. B., Pitts, J. P., and Walker, H. J. (2007). “Organizational change recipients' beliefs scale: Development of an assessment instrument", The Journal of Applied Behavioral Science, Vol.43 No. 4, pp. 481-505.

Armenakis, A. A. and Harris, S. G. (2002), "Crafting a change message to create transformational readiness", Journal of Organizational Change Management, Vol. 15 No. 2, pp. 169-183.

Armenakis, A.A., Harris, S.G. and Mossholder, K.W. (1993), “Creating readiness for organizational change”, Human Relations, Vol. 46 No. 6, pp. 681-704.

Axtell, C., Wall, T., Stride, C., Pepper, K., Clegg, C., Gardner, P. and Bolden, R. (2002), "Familiarity breeds content: The impact of exposure to change on employee openness 
and well-being”, Journal of Occupational and Organizational Psychology, Vol.75 No. 2, pp. 217-231.

Bäesu, C. and Bejinaru, R. (2014), “Leadership approaches regarding the organizational change", The USV annals of economics and public administration, Vol. 13 No. 22 (18), pp.146-152.

Bartunek, J. M., Rousseau, D. M., Rudolph, J. W. and DePalma, J. A. (2006), “On the receiving end: Sensemaking, emotion, and assessments of an organizational change initiated by others”, The Journal of Applied Behavioral Science, Vol. 42 No. 2, pp. 182-206.

Berman, S. (2012), "Digital transformation: opportunities to create new business models", Strategy \& Leadership, Vol. 40 No. 2, pp. 16-24.

Bernerth, J., (2004). "Expanding our understanding of the change message", Human Resource Development Review, Vol. 3 No.1, pp. 36-52.

Bersin, J., Flynn, J., Mazor, A., and Melian, V. (2017), “The employee experience: Culture, engagement, and beyond. 2017 Global Human Capital Trends. Deloitte Insights”, available at: https://www2.deloitte.com/insights/us/en/focus/human-capitaltrends/2017/improving-the-employee-experience-culture-engagement.html.

Bouckenooghe, D. (2010), “Positioning change recipients' attitudes toward change in the organizational change literature”. Journal of Applied Behavioral Science, Vol. 46 No. 4, pp. 500-531.

Bouckenooghe, D., Devos, G. and Van Den Broeck, H. (2008), “The change climate questionnaire: Scale development”, working paper [2008/511], Vlerick Leuven Ghent Management School, University of Gent, Gent. April 2008.

Bruch, H., \& Vogel, B. (2011). Fully charged: How great leaders boost their organization's energy and ignite high performance, Harvard Business Press, Boston. 
Buono, A.F. and Kerber, K.W. (2010), "Intervention and organizational change: Building organizational change capacity", EBS Review, Vol. 27, pp. 9-21.

Cameron, E. and Green, M. (2004), "Making Sense of Change Management: A Complete Guide to the Models, Tools and Techniques of Organizational Change”, Kogan Page Limited, London.

Christensen, C.M. (1997, 2013). The innovator's dilemma: when new technologies cause great firms to fail, Harvard Business Review Press, Cambridge.

Claiborne, N., Auerbach, C., Lawrence, C. and Schudrich, W. Z. (2013), “Organizational

change: The role of climate and job satisfaction in child welfare workers' perception of readiness for change", Children and Youth Services Review, Vol. 35 No 12, pp. 20132019.

Choi, M. (2011), Employees' attitudes toward organizational change: A literature review. Human Resource Management, Vol. 50 No. 4, pp. 479-500.

Cunningham, C.E., Woodward, C.A., Shannon, H.S., MacIntosh, J., Lendrum, B., Rosenbloom, D., and Brown, J., (2002), "Readiness for organizational change: a longitudinal study of workplace: psychological and behavioral correlates", Journal of Occupational and Organizational Psychology, Vol. 75, pp. 377-392.

Decker, P., Durand, R., Mayfield, C.O., McCormack, C., Skinner, D., and Perdue, G. (2012), "Predicting implementation failure in organization change" Journal of Organizational Culture, Communications and Conflict, Vol. 16 No. 2, pp. 29-50.

Del Val, M. P., and Fuentes, C. M (2003), "Resistance to change: A literature review and empirical study", Management Decision, Vol. 16 No. 2, pp. 148-155. 
Devos, G., Buelens, M. and Bouckenooghe, D. (2007), “Contribution of content, context, and process to understanding openness to organizational change: Two experimental simulation studies”, Journal of Social Psychology, Vol. 147 No. 6, pp. 607-630.

Dubois, A. and Gadde, L. E. (2002), "Systematic combining: An abductive approach to case research", Journal of Business Research, Vol. 55 No. 7, pp. 553-560.

Elias, S. M. (2009), "Employee commitment in times of change: Assessing the importance of Attitudes toward organizational change”, Journal of Management, Vol. 35 No. 1, pp. 3755.

Fedor, D. B., Caldwell, S. and Herold, D. M. (2006), "The effects of organizational changes on employee commitment: A multilevel investigation”, Personnel Psychology, Vol. 59 No. 1, pp. 1-29.

Flanding, J.P., Grabman, G.M., and Cox, S.Q. (2018). The technology takers: leading change in the digital era, Emerald Group Publishing, Bingley.

Forbes (2018), Top 100 digital companies, available at: https://www.forbes.com/top-digital-companies/list/2/\#tab:rank.

Fox, D. G., Ellison, R. L. and Keith, K. L. (1988), "Human resource index management: An and its relation- ship to readiness for change", Public Personnel Management, Vol. 17 No. 3, pp. 297-302.

Frow, P., Nenonen, S., Payne, A., and Storbacka, K. (2015). "Managing co-creation design: A strategic approach to innovation", British Journal of Management, Vol. 26 No. 3, pp. 463-483.

Gallup (n/d). Employee engagement survey questions. Available from: 
https://q12.gallup.com/public/en-us/Features.

Goold, M., and Campbell, A. (2002). Designing effective organizations: How to create structured networks. Jossey-Bass, San Francisco.

Groves, K.S. (2005), “Linking leader skills, follower attitudes, and contextual variables via an integrated model of charismatic leadership", Journal of Management, Vol. 31 No. 2, pp. 255-277.

Hanson, W. E., Creswell, J. W., Clark, V. L. P., Petska, K. S., and Creswell, J. D. (2005), "Mixed

methods research designs in counseling psychology", Journal of Counseling Psychology, Vol. 52 No. 2, pp. 224-235.

Heim, I., Han, T., and Ghobadian, A. (2018), "Value co-creation in ICT services company: A case study of a cross-border acquisition", Journal of East-West Business, Vol. 24 No. 4, pp. 319-338.

Herold, D.M., Caldwell, S. and Liu, Y. (2008), “The effects of transformational and change leadership on employees' commitment to a change: A multilevel study. Journal of Applied Psychology, Vol. 93 No. 2, pp. 346-357.

Herscovitch, L. (2003), "Resistance to organizational change: Toward a multidimension conceptualization" (unpublished doctoral dissertations). University of Western Ontario, Ontario, Canada.

Herscovitch, L., and Meyer, J. P. (2002), “Commitment to organizational change: Extension of

of a three-component model", Journal of Applied Psychology, Vol. 87 No.3, pp. 474487. 
Hertel, B., van der Heijden, I.J.M., de Lange, A.H., Guido, J.D., and Kunze F. (2013),

"Age, resistance to change, and job performance", Journal of Managerial Psychology, Vol. 28 No. 7/8, pp. $741-760$.

Higgs, M. and Rowland, D. (2000). "Building change leadership capability: The quest for change competence", Journal of Change Management, Vol. 1 No.2, pp. 116-130.

Higgs, M.J., and Rowland, D. (2001), "Developing change leaders: Assessing the impact of a development programme”, Journal of Change Management, Vol. 2 No.1, pp. 47-64.

Higgs, M. and Rowland, D. (2005), “All changes great and small: Exploring approaches to change and its leadership", Journal of Change Management, Vol. 5 No. 2, pp. 121151.

Higgs, M. and Rowland, D. (2011), "What does it take to implement change successfully?

A study of the behaviors of successful change leaders", Journal of Applied Behavioural Science, Vol. 47 No. 3, pp. 309-335.

Hoogerhuis, M and Anderson, J. (2019). "How to adapt to constant change: create it", available at: https://www.gallup.com/topic/change_management.aspx.

Holt, D.T. and Vardaman, J.M. (2013), “Toward a comprehensive understanding of readiness for change: The case for an expanded conceptualization", Journal of Change Management, Vol. 13 No.1, pp. 9-18.

Holt, D.T., Armenakis, A.A., Feild, H.S. and Harris, S.G. (2007a), "Readiness for Organizational Change. The systematic development of a Scale", The Journal of Applied Behavioural Science, Vol. 43 No.2, pp. 232-255.

Holt, D.T., Armenakis, A.A., Harris, S.G. and Feild, H.S. (2007b), “Toward a 
comprehensive definition of readiness for change: A review of research and instrumentation", In: Pasmore, W.A. and Woodman, R.W.(Eds.), Research in Organizational Change and Development, Emerald Group Publishing Limited, Bingley, pp. 289-336.

Huy, Q.N. (1999), “Emotional capability, emotional intelligence, and radical change”, Academy of Management Review, Vol. 24 No. 2, pp. 325-345.

Jansen, H. (2010), "The logic of qualitative survey research and its position in the field of social research methods", Forum Qualitative Sozialforschung/Forum: Qualitative Social Research, Vol. 11 No. 2, Art. 11, pp. 1-21.

Jones, R.A., Jimmieson, N.L., and Griffiths, A. (2005). "The impact of organizational culture and reshaping capabilities on change implementation success: The mediating role of readiness for change", Journal of Management Studies, Vol. 42, No. 2, pp. 361-386.

Kim, T.G., Hornung, S. and Rousseau, D.M. (2011). "Change-supportive employee behavior: Antecedents and the moderating role of time", Journal of Management, Vol. 37 No. 6, pp. 1664-1693.

Klein, K.J., and Sorra, J.S. (1996), “The challenge of innovation implementation”, Academy of Management Review, Vol. 21 No.4, pp. 1055-1080.

Kotter, J.P. (1995). "Leading change: Why transformation efforts fail”, Harvard Business Review, March-April: 59-67.

Kotter, J.P. (2012). Leading change, Harvard Business School Press, Cambridge.

Kunze, F., Boehm, S. and Bruch, H. (2011), “Age diversity, age discrimination climate and performance consequences - a cross organizational study", Journal of Organizational Behavior, Vol. 32 No.2, pp. 264-290. 
Kwahk, K.-Y., and Kim, H.-W. (2008), "Managing readiness in enterprise systems-driven organizational change", Behaviour \& Information Technology, Vol. 27 No.1, pp. 7987.

Lawrence, P.R. (1969). "How to deal with resistance to change", Harvard Business Review, Vol. 47 January No. 1, pp. 4-6.

Madsen, S.R., Miller, D. and John, C.R. (2005), "Readiness for organizational change: Do organizational commitment and social relationships in the workplace make a difference?" Human Resource Development Quarterly, Vol. 16 No.2, pp. 213-233.

Miller, V.D., Johnson, J.R., and Grau, J. (1994), “Antecedents to willingness to participate in a planned organizational change", Journal of Applied Communication Research, Vol. 22 No.1, pp. 59-80.

Niessen, C., Swarowsky, C. and Leiz, M. (2010), "Age and adaptation to changes in the workplace", Journal of Managerial Psychology, Vol. 25 No.4, pp. 356-383.

Nink, M. and Welte, K. (2011). "Involving employees in change”, Available from: https://news.gallup.com/businessjournal/150932/involving-employees-change.aspx

Oreg, S. (2006). "Personality, context, and resistance to organizational change", European Journal of Work and Organizational Psychology, Vol. 15 No.1, pp. 73-101.

Oreg, S., Bartunek, J.M., Lee, G., and Do, B. (2016). “An affect-based model of recipients' responses to organizational change events", Academy of Management Review, Vol. 43 No. 1, pp. 65-86.

Oreg, S., Vakola, M., and Armenakis, A. (2011). “Change recipients' reactions to organizational change: A 60-year review of quantitative studies", The Journal of Applied Behavioral Science, Vol. 47 No. 4, pp. 461-524. 
Ostroff, C. and Clark, M.A. (2001), "Maintaining an internal market: Antecedents of willingness to change jobs", Journal of Vocational Behavior, Vol. 59 No. 3, pp. 425453.

Pan, W. and Sun, L. (2018), “A self-regulation model of Zhong Yong thinking and employee adaptive performance”, Management and Organization Review, Vol. 14 No. 1, pp. 135159.

Pellettiere, V. (2006), “Organization self-assessment to determine the readiness and risk for a planned change", Organization Development Journal, Vol. 24 No. 4, pp.38-43.

Piderit, S.K. (2000), "Rethinking resistance and recognizing ambivalence: A multidimensional view of attitudes toward an organizational change", Academy of Management Review, Vol. 25 No. 4, pp. 783-794.

Rafferty, A.E., Jimmieson, N.L. and Armenakis, A.A. (2013), “Change readiness: A multilevel review", Journal of Management, Vol. 39 No. 1, pp. 110-135.

Rafferty, A.E., and Minbashian, A. (2018), “Cognitive beliefs and positive emotions about change: Relationships with employee change readiness and change-supportive behaviors.”, Human Relations, Vol. 72 No. 10, pp. $1623-1650$.

Rafferty, A.E., and Simons, R. (2006), “An examination of the antecedents of readiness for fine-tuning and corporate transformation changes", Journal of Business \& Psychology, Vol. 20 No. 3, pp. 325- 350.

Rafferty, A.E., and Restubog, S. (2017), “Why do employees' perceptions of their organization's change history matter? The role of change appraisals", Human Resource Management, Vol.56 No.3, pp. 533-550.

Rashid, Z.A., Sambasivan, M., and Rahman, A.A. (2004), “The influence of 
organizational culture on attitudes toward organizational change", Leadership \& organization development Journal. Vol. 25 No. 2, pp. 161-179.

Repovš, E., Drnovšek, M., and Kaše, R. (2019), “Change ready, resistant, or both? Exploring the concept of individual change readiness and resistance to organizational change", Economic and Business Review for Central and South-Eastern Europe, Vol. 21 No.2, pp. 309-343.

Robinson, S.L. (2019), "What is a pre-theory paper? Some insights to help you recognize or create a pre-theory paper for AMD”, Academy of Management Discoveries, Vol. 5 No.1, pp. 1-7.

Shah, N., Irani, Z., and Sharif, A.M. (2017), "Big data in an HR context: Exploring organizational change readiness, employee attitudes and behaviors", Journal of Business Research, Vol. 70, pp. 366-378.

Schalk, R., Campbell, W.J. and Freese, C. (1998), "Change and employee behavior”, Leadership \& Organization Development Journal, Vol. 19 No.3, pp. 157-163.

Schein, E.H. (1984), “Coming to a new awareness of organizational culture”, Sloan Management Review, Vol. 25 No. 2, pp. 3-16.

Schein, E.H. (2010), Organizational Culture and Leadership, Jossey-Bass, San Francisco.

Schneider, B. and Brief, A. (1996), "Creating a climate and culture for sustainable organizational change”, Organizational Dynamics, Vol. 24 No. 7, pp. 7-19.

Secord, P.F., and Backman. C.W. (1969), Social Psychology, McGraw Hill, New York. Self, D.R., and Schräder, M. (2009), "Enhancing the success of organizational change: Matching readiness strategies with sources of resistance", Leadership \& Organization Development Journal, Vol. 30 No. 2, pp. 167-182. 
Silvester, J., and Anderson, N.R. (1999), “Organizational culture change”, Journal of Occupational \& Organizational Psychology, Vol. 72 No. 1, pp. 1-24.

Vakola, M. (2013), “Multilevel readiness to organizational change: A conceptual approach”, Journal of Change Management, Vol. 13 No.1, pp. 96-109.

Vakola, M. (2014), “What's in there for me? Individual readiness to change and the perceived impact of organizational change", Leadership \& Organization Development Journal, Vol. 35 No .3, pp. 195-209.

Vakola, M. and Nikolaou, I. (2005), “Attitudes towards organizational change: What is the role of employees' stress and commitment?”, Employee Relations, Vol. 27 No.2, pp. 160174.

Van der Smissen, S., Schalk, R. and Freese, C. (2013), "Organizational change and the psychological contract: How change influences the perceived fulfillment of obligations", Journal of Organizational Change Management, Vol. 26 No.6, pp. 1071-1090.

Van Echtelt, F., Wynstra, F., van Weele, A. and Duysters, G. (2008). "Managing supplier involvement in new product development: a multiple-case study", Journal of Product Innovation Management, Vol. 25, pp. 180-201.

Walker, H.J., Armenakis, A.A., and Bernerth, J.B. (2007), “Factors influencing organizational change efforts: An integrative investigation of change content, context, process and individual differences", Journal of Organizational Change Management, Vol. 20 No. 6, pp. 761-773.

Wanberg, C.R. and Banas, J.T. (2000), "Predictors and outcomes of openness to changes in a reorganizing workplace”, Journal of Applied Psychology, Vol. 85 No.1, pp. 132-142. 
Wanous, J.P., Reichers, A.E., and Austin, J.T. (2004), “Cynicism about organizational change:

An attribution process perspective", Psychological Reports, Vol. 94 No.3, pp. 14211434.

Weber, P.S. and Weber, J.E. (2001), “Changes in employee perceptions during organizational change", Leadership \& Organization Development Journal, Vol. 22 No.6, pp. 291-300.

Weiner, B.J. (2009), “A theory of organizational readiness for change”, Implementation Science, Vol. 67, No.4, pp. 67-75.

\section{Appendix. Survey questions.}

\begin{tabular}{|c|c|c|}
\hline $\mathbf{N}$ & Predictor & Questions/Statements \\
\hline \multicolumn{3}{|c|}{ How far do you agree with the following statements? } \\
\hline 1 & Age & What is your age? \\
\hline 2 & Gender & What is your gender? \\
\hline 3 & Company background & What is the name of your previous company? \\
\hline 4 & Job seniority & $\begin{array}{l}\text { How long have you been with / working for the Organization } \\
\text { including the predecessor company? }\end{array}$ \\
\hline 5 & Job function & What is your job function? \\
\hline 6 & Job satisfaction & Are you satisfied in your current job? \\
\hline 7 & \multirow{3}{*}{$\begin{array}{l}\text { Individual perception } \\
\text { of organizational } \\
\text { culture }\end{array}$} & $\begin{array}{l}\text { I am aware of the values of the Organization and can identify } \\
\text { with them. }\end{array}$ \\
\hline 8 & & I am aware and support the vision of the Organization. \\
\hline 9 & & $\begin{array}{l}\text { I feel that the culture in the Organization is open and receptive } \\
\text { to new ideas, innovation, and change. }\end{array}$ \\
\hline 10 & \multirow{3}{*}{$\begin{array}{l}\text { Understanding the } \\
\text { need \& urgency for } \\
\text { change }\end{array}$} & $\begin{array}{l}\text { I understand the current organizational challenges in the } \\
\text { Organization. }\end{array}$ \\
\hline 11 & & $\begin{array}{l}\text { My executive management communicates regularly on the } \\
\text { current challenges of the Organization. }\end{array}$ \\
\hline 12 & & $\begin{array}{l}\text { I understand that there is a need for a change in the Organization } \\
\text { as soon as possible. }\end{array}$ \\
\hline 13 & \multirow{3}{*}{$\begin{array}{l}\text { General attitude at } \\
\text { workplace-willingness } \\
\text { to change }\end{array}$} & I feel I am ready for another organizational change. \\
\hline 14 & & I welcome organizational change as a positive challenge. \\
\hline 15 & & $\begin{array}{l}\text { I am open to switching jobs in } 6-12 \text { months if required by } \\
\text { organizational change. }\end{array}$ \\
\hline 16 & \multirow{2}{*}{$\begin{array}{l}\text { Trust in oneself-self } \\
\text { efficacy-ability to } \\
\text { change }\end{array}$} & $\begin{array}{l}\text { My past experiences make me confident that I will be able to } \\
\text { perform successfully after an organizational change is made. }\end{array}$ \\
\hline 17 & & $\begin{array}{l}\text { Though I may need some support, I have little doubt I can } \\
\text { perform well, following any restructuring. }\end{array}$ \\
\hline
\end{tabular}




\begin{tabular}{|c|c|c|}
\hline 18 & & $\begin{array}{l}\text { I do not anticipate any problems adjusting to the work I will } \\
\text { have when organizational change is adopted. }\end{array}$ \\
\hline 19 & \multirow{4}{*}{$\begin{array}{l}\text { Individual perception } \\
\text { of organizational } \\
\text { capabilities to change }\end{array}$} & $\begin{array}{l}\text { I believe that the Organization has been able to cope } \\
\text { effectively with new situations. }\end{array}$ \\
\hline 20 & & $\begin{array}{l}\text { I believe that past changes in the Organization resulted in } \\
\text { improvements. }\end{array}$ \\
\hline 21 & & $\begin{array}{l}\text { I believe that the Organization has proven itself capable of } \\
\text { implementing organizational changes. }\end{array}$ \\
\hline 22 & & $\begin{array}{l}\text { The Organization generally provides appropriate support when } \\
\text { I need them to cope with organizational changes. }\end{array}$ \\
\hline 23 & \multirow{3}{*}{$\begin{array}{l}\text { Quality of } \\
\text { communication }\end{array}$} & $\begin{array}{l}\text { The communication I receive from the Organization centrally } \\
\text { is timely and useful. }\end{array}$ \\
\hline 24 & & $\begin{array}{l}\text { Information on upcoming changes does not first come to us as } \\
\text { rumours. }\end{array}$ \\
\hline 25 & & $\begin{array}{l}\text { My line manager and the Organization management } \\
\text { communicate on a regular basis on upcoming changes. }\end{array}$ \\
\hline 26 & \multirow[t]{5}{*}{$\begin{array}{l}\text { Past experience with } \\
\text { change }\end{array}$} & $\begin{array}{l}\text { What was the name of the last reorganization change you were } \\
\text { involved in? }\end{array}$ \\
\hline 27 & & $\begin{array}{l}\text { Was the goal of this organization change you experienced clear } \\
\text { to you? }\end{array}$ \\
\hline 28 & & Was the change successful in your opinion? \\
\hline 29 & & What did you like the most in the change? \\
\hline 30 & & What can be improved for changes in the future? \\
\hline \multicolumn{3}{|c|}{ Answer the following questions keeping the recent organizational change in mind } \\
\hline 31 & $\begin{array}{l}\text { Past experience with } \\
\text { change/ change } \\
\text { communication }\end{array}$ & $\begin{array}{l}\text { The information I received about that change was timely and } \\
\text { useful }\end{array}$ \\
\hline 32 & \multirow[t]{2}{*}{$\begin{array}{l}\text { Past experience with } \\
\text { change/change support }\end{array}$} & $\begin{array}{l}\text { I was able to express the support I needed to my manager and } \\
\text { was given the necessary support. }\end{array}$ \\
\hline 33 & & $\begin{array}{l}\text { I was able to ask questions about the changes that had been } \\
\text { proposed and voice my opinion about the change }\end{array}$ \\
\hline 34 & $\begin{array}{l}\text { Past experience with } \\
\text { change participation }\end{array}$ & $\begin{array}{l}\text { I was able to participate in the planning and implementation of } \\
\text { the change }\end{array}$ \\
\hline 35 & \multirow[t]{3}{*}{$\begin{array}{l}\text { Past experience with } \\
\text { change leadership } \\
\text { behaviour }\end{array}$} & $\begin{array}{l}\text { My manager was able to emotionally connect me to the change } \\
\text { by inspiring and challenging me to deliver the change through } \\
\text { motivation }\end{array}$ \\
\hline 36 & & $\begin{array}{l}\text { My manager provided the emotional, temporal, and physical } \\
\text { space to enable me to think and act differently. }\end{array}$ \\
\hline 37 & & $\begin{array}{l}\text { My manager was controlling what needed to be done, } \\
\text { allocating tasks, expressing his/her view of the change. }\end{array}$ \\
\hline 38 & $\begin{array}{l}\text { Reasons for change in } \\
\text { the future }\end{array}$ & $\begin{array}{l}\text { What in your opinion needs to change to tackle the current } \\
\text { challenges in the Organization? }\end{array}$ \\
\hline 39 & $\begin{array}{l}\text { Requirements for } \\
\text { future organizational } \\
\text { changes: change } \\
\text { communication }\end{array}$ & How frequently do you want to hear about the change? \\
\hline
\end{tabular}


40 Requirements for future organizational changes: change communication

41 Most valued change leadership behaviour during an

42 organizational change/change

43 leadership behaviour

What is the most effective channel of communication about the change?

I want my leader to establish an emotional connection to the change and to create a compelling story for the organization about the change.

I want my leader to tell the whole truth about the change and motivate everyone to deliver the change.

I want my leader to set boundaries and expectations for the change.

I want my leader to create ownership, trust and confidence.

I want my leader to encourage others to voice their opinions through empathy and high-quality dialogue skills.

I want my leader to provide the emotional, temporal, and physical space for me to think and act differently during the change.

I want my leader to closely manage relevant tasks and hold others responsible for delivering task for the change.

I want my leader to express his own views and use his experience to shape the implementation of the change.

I want my leader to be persuasive and expressive.

50 Phase of energy in the organization

Which phase of energy do you see your colleagues currently have in the Organization? Corrosive energy, productive energy, comfortable, resigned energy?

51 Key success factors for What, in your opinion, are the key success factors for making making organizational organizational change successful in the Organization? change successful

\begin{tabular}{|l|l|l}
52 & Ways to bring a & What, in your opinion, are the three top ways to bring a
\end{tabular} mindset change mindset change in the organization? 
Table 1.

Definition and explanation of constructs of employee attitudes.

\begin{tabular}{|l|l|l|}
\hline \multicolumn{1}{|c|}{ Construct } & \multicolumn{1}{c|}{ Definition } & \multicolumn{1}{c|}{ Indicative literature } \\
\hline $\begin{array}{l}\text { Readiness for } \\
\text { change }\end{array}$ & $\begin{array}{l}\text { Extent to which an individual believes that a } \\
\text { change at the individual level is needed and } \\
\text { whether he or she has the capacity for it }\end{array}$ & $\begin{array}{l}\text { Armenakis } \text { et al., 1993 } \\
\text { Holt } \text { et al., 2007a } \\
\text { Holt } \text { et al., 2007b } \\
\text { Holt \& Vardaman 2013 }\end{array}$ \\
\hline $\begin{array}{l}\text { Commitment to } \\
\text { change }\end{array}$ & $\begin{array}{l}\text { A mindset that binds an individual to a course of } \\
\text { action deemed necessary for the successful } \\
\text { implementation of a change initiative }\end{array}$ & $\begin{array}{l}\text { Herscovitch \& Meyer 2002 } \\
\text { Fedor } \text { et al., 2006 } \\
\text { Herold } \text { et al., 2008 } \\
\text { Choi, 2011 }\end{array}$ \\
\hline $\begin{array}{l}\text { Openness to } \\
\text { change }\end{array}$ & $\begin{array}{l}\text { An underlying trait of flexibility and assumes } \\
\text { creativity, curiosity, and artistically sensitivity, } \\
\text { i.e. "willingness to accommodate and accept } \\
\text { change" }\end{array}$ & $\begin{array}{l}\text { Fox } \text { et al., 1988 } \\
\text { Miller } \text { et al., 1994 } \\
\text { Wanberg \& Banas, 2000 } \\
\text { Axtell } \text { et al., 2002 } \\
\text { Groves, 2005 } \\
\text { Madsen } \text { et al., 2005 } \\
\text { Devos } \text { et al., 2007 } \\
\text { Kwahk \& Kim, 2008 } \\
\text { Choi, 2011 }\end{array}$ \\
\hline $\begin{array}{l}\text { Cynicism about } \\
\text { organizational } \\
\text { change }\end{array}$ & $\begin{array}{l}\text { Pessimism about future organizational change } \\
\text { being successful, a dispositional attribution of the } \\
\text { failure (the motivation and competence of } \\
\text { organizational leaders) and/or a situational } \\
\text { attribution of the failure }\end{array}$ & Wanous et al., 2004 \\
\hline
\end{tabular}


Table 2.

Independent variables.

\begin{tabular}{|c|c|c|}
\hline $\begin{array}{ll}\text { Variable } \\
\end{array}$ & Type & Indicative literature \\
\hline Age & Demographic & $\begin{array}{l}\text { Niessen et al. (2010) } \\
\text { Kunze et al. (2011) } \\
\text { Hertel et al. (2013) }\end{array}$ \\
\hline Gender & Demographic & $\begin{array}{l}\text { Alas (2008) } \\
\text { Ostroff \& Clark } 2001\end{array}$ \\
\hline Job level and function & Demographic & Alas (2008) \\
\hline Tenure in the company & Demographic & Alas (2008) \\
\hline Company background of the employee & Demographic & Van der Smissen et al. (2013) \\
\hline $\begin{array}{l}\text { Individual perception of organizational } \\
\text { culture }\end{array}$ & Internal context enabler & Choi (2011) \\
\hline $\begin{array}{l}\text { Understanding the need and urgency } \\
\text { for change }\end{array}$ & Internal context enabler & Armenakis et al. (2007) \\
\hline $\begin{array}{l}\text { Individual perception of organizational } \\
\text { capabilities }\end{array}$ & Internal context enabler & Choi (2011) \\
\hline Quality of communication & Internal context enabler & Choi (2011) \\
\hline Trust in leadership & Internal context enabler & $\begin{array}{l}\text { Rafferty \& Simons }(2006) \\
\text { Bouckenooghe et al. }(2008) \\
\text { Higgs \& Rowland }(2000,2001,2005) \\
\text { Higgs \& Rowland }(2011)\end{array}$ \\
\hline Past experience with change & Internal context enabler & $\begin{array}{l}\text { Rafferty et al. (2012) } \\
\text { Raffery \& Restuborg (2016) }\end{array}$ \\
\hline $\begin{array}{l}\text { Change participation as a part of past } \\
\text { experience with change }\end{array}$ & Internal context enabler & Bouckenooghe et al. (2008) \\
\hline
\end{tabular}


Table 3.

Open comments on "I feel I am ready for another organizational change".

\begin{tabular}{|l|c|c|}
\hline Free text comments on willingness to change & N of responses & \% of total \\
\hline No comments & 263 & 85.95 \\
\hline Open to internal job change only when it is meaningful & 21 & 6.86 \\
\hline Dissatisfaction due to past change & 9 & 2.94 \\
\hline Question on change itself & 7 & 2.29 \\
\hline Dissatisfaction due to constant state of change & 5 & 1.63 \\
\hline Not open to job change & 2 & 0.65 \\
\hline Grand Total & 306 & 100.00 \\
\hline
\end{tabular}

Source: primary data collected through online survey. 
Table 4.

Open comments on the question

"I believe that the organization has been able to cope effectively with new situation".

\begin{tabular}{|l|c|c|}
\hline Free text comments on willingness to change & N of responses & \% of total \\
\hline No comments & 274 & 89.54 \\
\hline $\begin{array}{l}\text { Dissatisfaction about working in the organization (processes, tools, } \\
\text { management, near \& offshoring) }\end{array}$ & 9 & 2.94 \\
\hline Answer not related to the question & 6 & 1.96 \\
\hline Dissatisfaction about past change & 5 & 1.63 \\
\hline Processes and tools must be a part of the org change & 4 & 1.31 \\
\hline $\begin{array}{l}\text { Lack of trust on change implementation management capabilities in the } \\
\text { organization }\end{array}$ & 3 & 0.98 \\
\hline Lack of support from the organization to cope with org change & 2 & 0.65 \\
\hline Positive comment on organizational capabilities & 2 & 0.65 \\
\hline Question about the upcoming change & 1 & 0.33 \\
\hline Grand Total & 306 & 100.00 \\
\hline
\end{tabular}

Source: primary data collected through the online survey. 
Table 5.

Individual perception of organizational capabilities to change and willingness and ability to change questions.

\begin{tabular}{|l|r|r|r|r|}
\hline Question & $\begin{array}{l}\text { I believe that the } \\
\text { organization has } \\
\text { been able to cope } \\
\text { effectively with } \\
\text { new situations }\end{array}$ & $\begin{array}{l}\text { Ibelieve that } \\
\text { past changes in } \\
\text { the organization } \\
\text { resulted in } \\
\text { improvements }\end{array}$ & $\begin{array}{l}\text { I believe that the } \\
\text { organization has } \\
\text { proven itself } \\
\text { capable to } \\
\text { implementing } \\
\text { organizational } \\
\text { changes }\end{array}$ & $\begin{array}{l}\text { I feel I am ready } \\
\text { for another } \\
\text { organizational } \\
\text { change }\end{array}$ \\
\hline $\begin{array}{l}\text { I feel I am ready for another } \\
\text { organizational change }\end{array}$ & 0.089 & $0.153^{* *}$ & $0.126^{*}$ & 1.000 \\
\hline $\begin{array}{l}\text { My prior experiences make me } \\
\text { confident, that I will be able to } \\
\text { perform successfully after an } \\
\text { organizational change is made }\end{array}$ & $0.253^{* *}$ & $0.307^{* *}$ & $0.273^{* *}$ & $0.423^{* *}$ \\
\hline
\end{tabular}

** Significant at 0.01 level (two tailed). * Significant at 0.05 level (two tailed).

Source: primary data collected through online survey. 
Table 6

Results of change behavioral requirements from the online survey.

\begin{tabular}{|l|c|c|c|}
\hline \multicolumn{1}{|c|}{ Questions } & $\begin{array}{c}\text { N of } \\
\text { responses }\end{array}$ & $\begin{array}{c}\text { \% of } \\
\text { total }\end{array}$ & Change strategy \\
\hline $\begin{array}{l}\text { I want my leader to tell the reality as it is and motivate everyone } \\
\text { to deliver the change. }\end{array}$ & 251 & $82.03 \%$ & Framing \\
\hline $\begin{array}{l}\text { I want my leader to express his own views and use his } \\
\text { experience to shape the implementation of the change. }\end{array}$ & 133 & $43.46 \%$ & Shaping \\
\hline I want my leader to be persuasive and expressive. & 133 & $43.46 \%$ & Shaping \\
\hline $\begin{array}{l}\text { I want my leader to set boundaries and expectation for the } \\
\text { change for others to operate in. }\end{array}$ & 127 & $41.50 \%$ & Framing \& creating \\
\hline $\begin{array}{l}\text { I want my leader to provide a positive mood as well as the } \\
\text { temporal and physical space for me to think and act differently } \\
\text { during the change. }\end{array}$ & 116 & $37.91 \%$ & Creating \\
\hline $\begin{array}{l}\text { I want my leader to establish an emotional connection to the } \\
\text { change and create a compelling story for the organization } \\
\text { about the change. }\end{array}$ & 99 & $32.35 \%$ & Framing \\
\hline $\begin{array}{l}\text { I want my leader to control what gets done and hold others } \\
\text { responsible for delivering task for the change. }\end{array}$ & 98 & $32.03 \%$ & Shaping \\
\hline I want my leader to create ownership, trust and confidence. & 87 & $28.43 \%$ & Framing \& creating \\
\hline $\begin{array}{l}\text { I want my leader to encourage others to voice their opinions } \\
\text { through empathy and high quality dialog skills. }\end{array}$ & 78 & $25.49 \%$ & Creating \\
\hline
\end{tabular}

Source: primary data collected through online survey. 
Figure 1 . The relations amongst variables and willingness and ability to change. Source: Authors based on literature sources.

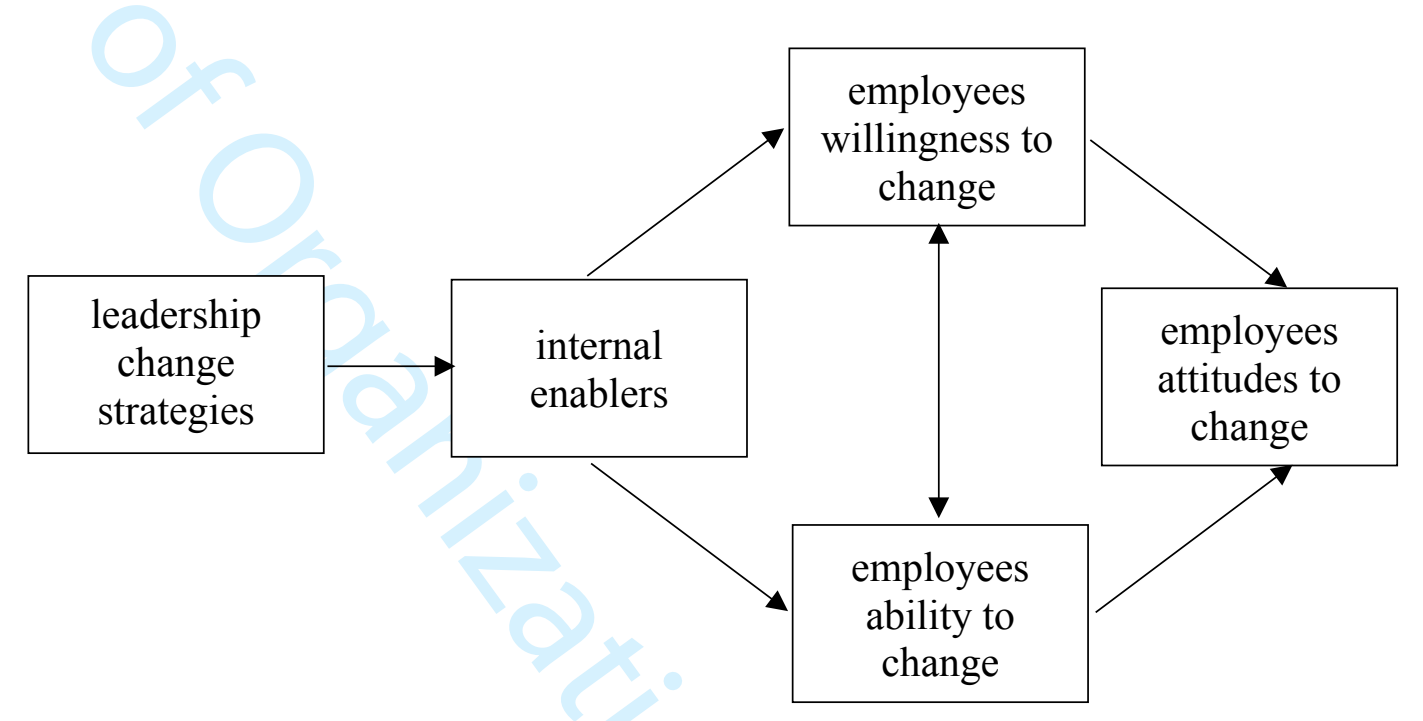


Figure 2. The relationships amongst variables and willingness and ability to change.

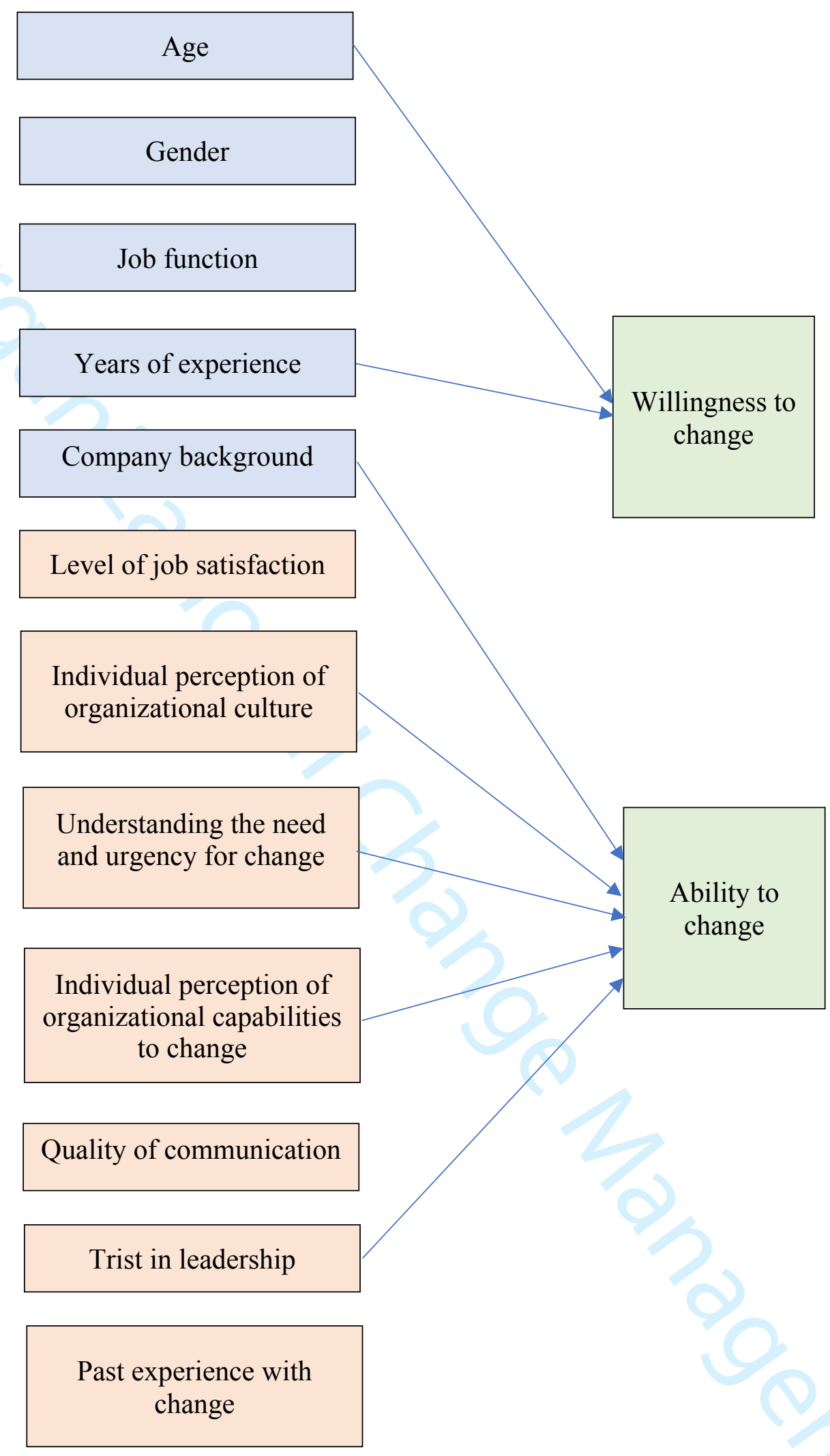

Source: Authors. 